May 2003 • NREL/CP-590-33580

\title{
The Effects of Processing Conditions on Polymer Photovoltaic Device Performance
}

A. Breeze, D. Ginley, and B. Gregg

Presented at the National Center for Photovoltaics and Solar Program Review Meeting Denver, Colorado March 24-26, 2003

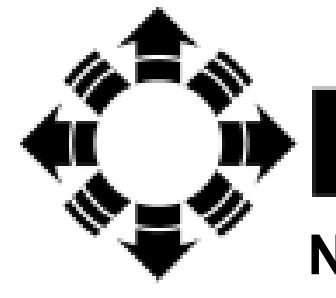

National Renewable Energy Laboratory

1617 Cole Boulevard Golden, Colorado 80401-3393

NREL is a U.S. Department of Energy Laboratory Operated by Midwest Research Institute $\bullet$ Battelle $\bullet$ Bechtel Contract No. DE-AC36-99-G010337 


\section{NOTICE}

The submitted manuscript has been offered by an employee of the Midwest Research Institute (MRI), a contractor of the US Government under Contract No. DE-AC36-99G010337. Accordingly, the US Government and MRI retain a nonexclusive royalty-free license to publish or reproduce the published form of this contribution, or allow others to do so, for US Government purposes.

This report was prepared as an account of work sponsored by an agency of the United States government. Neither the United States government nor any agency thereof, nor any of their employees, makes any warranty, express or implied, or assumes any legal liability or responsibility for the accuracy, completeness, or usefulness of any information, apparatus, product, or process disclosed, or represents that its use would not infringe privately owned rights. Reference herein to any specific commercial product, process, or service by trade name, trademark, manufacturer, or otherwise does not necessarily constitute or imply its endorsement, recommendation, or favoring by the United States government or any agency thereof. The views and opinions of authors expressed herein do not necessarily state or reflect those of the United States government or any agency thereof.

Available electronically at http://www.osti.gov/bridge

Available for a processing fee to U.S. Department of Energy and its contractors, in paper, from:

U.S. Department of Energy

Office of Scientific and Technical Information

P.O. Box 62

Oak Ridge, TN 37831-0062

phone: 865.576.8401

fax: 865.576.5728

email: reports@adonis.osti.gov

Available for sale to the public, in paper, from:

U.S. Department of Commerce

National Technical Information Service

5285 Port Royal Road

Springfield, VA 22161

phone: 800.553 .6847

fax: 703.605.6900

email: orders@ntis.fedworld.gov

online ordering: http://www.ntis.gov/ordering.htm

Printed on paper containing at least $50 \%$ wastepaper, including $20 \%$ postconsumer waste 


\title{
The Effects of Processing Conditions on Polymer Photovoltaic Device Performance
}

\author{
A. Breeze, D. Ginley and B. Gregg \\ National Renewable Energy Laboratory \\ 1617 Cole Blvd., Golden, CO 80401
}

\begin{abstract}
We will discuss recent results for the NREL polymer photovoltaics group. The work reported here explores the impact of polymer morphology on the physics and performance of polymer-based photovoltaic devices. By varying both the annealing temperatures and the solvent used for polym er deposition, we can alter the polymer chain morphology, thus shifting the absorption onset and shape and improving the charge transport properties of the resulting devices. The higher degree of order in the films results in increased photovoltaic performance.

\section{Introduction}

During the last decade, semiconducting polymers have been rapidly developing as a novel class of optoelectronic materials with applications including both light-emitting diodes (OLEDs) and photovoltaics. This is motivated in large part by their promise of low cost, low-toxicity manufacturing methods, tunable optical properties, and the possibility of lightweight, flexible large area panels. Although the two devices are fundamentally opposite (electricity in and light out for OLEDs and light in and electricity out for photovoltaics) many of the material and scientific issues for these devices are the same and as such, knowledge gained in one field is synergistic with the other.
\end{abstract}

\section{Polymer - Small Molecule Organic Composite Devices}

One of our primary focuses has been the use of polymer small molecule organic heterojuntion devices to probe key aspects of photovoltaic performance. The polymer - small molecule heterojunction interface exhibits high exciton dissociation efficiency, leading to power conversion efficiencies that are greater than cells constructed from either component alone. [1] Typically, electron conducting perylene benzimidazole (PBI) (Figure 1b) films are thermally evaporated to a thickness of $20 \mathrm{~nm}$. The hole conducting polymer, regioregular poly(3-hexylthiophene) (P3HT) (Figure 1a), is then spin cast from an $8 \mathrm{~g} / 1$ solution in either chloroform or chlorobenzene to create films of 35 $\mathrm{nm}$ thickness. P3HT has been chosen both for its increased absorption spectrum (absorption is extended up to $650 \mathrm{~nm}$, whereas the commonly used PPV-based polymer absorption cuts off at $600 \mathrm{~nm}$ ) as well as its tendency to form more ordered polymer chain film morphologies, with corresponding improvements in charge transport properties. These photoactive layers are sandwiched between patterned indium tin oxide (ITO) and gold electrodes. Here we report on the effects of processing conditions such as solvent choice and annealing temperature on the polymer film morphology. Power conversion efficiencies of $0.47 \%$ have been achieved for these planar devices, with open-circuit voltage of $\mathrm{V}_{\mathrm{oc}}=-0.33 \mathrm{~V}$, short-circuit current density of $\mathrm{J}_{\mathrm{sc}}$ $=4 \mathrm{~mA} / \mathrm{cm}^{2}$ and a fill factor of $\mathrm{ff}=35 \%$ at one-sun incident light. In comparison to similar devices using the polymer M3EH-PPV [1] in place of P3HT, the polythiophene devices exhibit higher short-circuit current, though the fill factor and especially the open-circuit voltage are reduced. Experiments to determine and hopefully circumvent the reduction in photovoltage are currently underway.

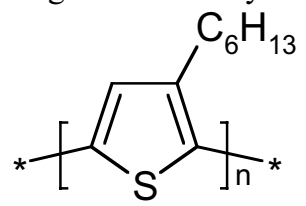

(a)

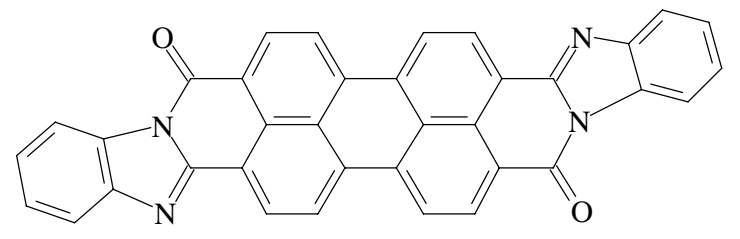

(b)

Fig 1. Chemical structures of (a) regioregular P3HT and (b) PBI.

\section{Effects of Polymer Annealing Temperature}

The degree of order in polymer films can have a drastic effect on both absorption properties and charge transport. Regiorandom P3HT, for example, differs from the regioregular material only by the random variation of the $\mathrm{C}_{6} \mathrm{H}_{13}$ side groups from position 3 to position 4 on the thiophene ring, whereas the position is fixed at 3 for the regioregular material. This has a drastic effect on the absorption: the absorption peak for the regioregular material is shifted to lower energies and shows more vibronic structure, all indicative of a higher degree of polymer chain ordering. It has also been demonstrated that the regiorandom material excitations consist primarily of intrachain excitons, whereas the regioregular material has a larger inter-chain component. [2]

We have demonstrated that the polymer chain morphology can be further influenced through both the film annealing temperature and the choice of solvent for the polymer depositon. Figure 2 compares the absorption spectra of various regioregular P3HT films as a function of annealing temperature. As the annealing temperature is increased 
from no annealing (ambient room temperature) to $155^{\circ} \mathrm{C}$ and finally to $240^{\circ} \mathrm{C}$, the strength of the peaks at both 550 $\mathrm{nm}$ and $600 \mathrm{~nm}$ increases. This indicates an increasing degree of ordering of the polymer chains in the film. [3]

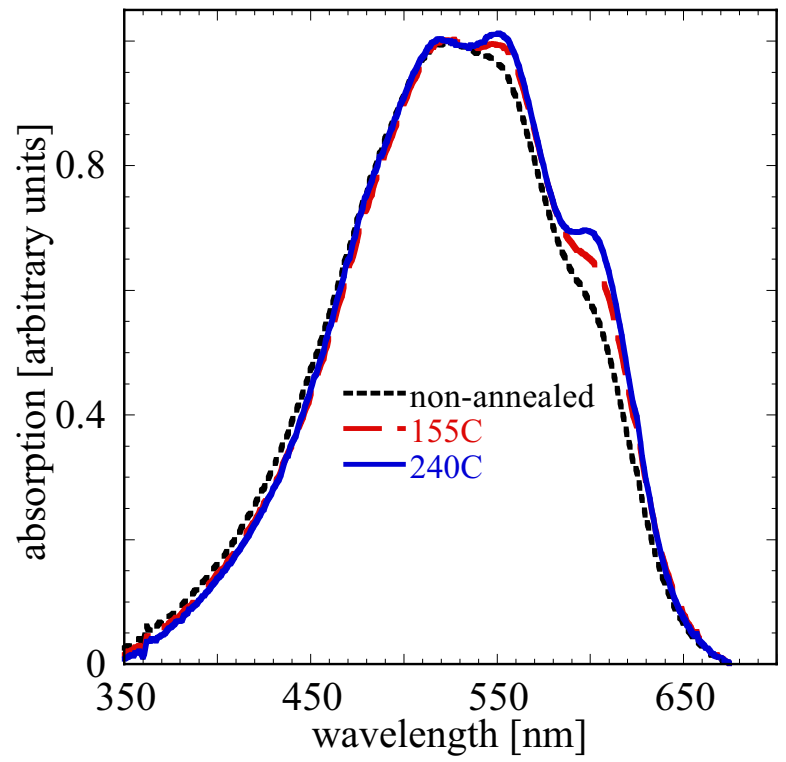

Fig 2. Absorption spectra for non-annealed (dotted black), $155^{\circ} \mathrm{C}$ annealed (dashed red) and $240^{\circ} \mathrm{C}$ annealed (solid blue) P3HT films. Absorption is normalized at the $522 \mathrm{~nm}$ peak for comparison purposes.

Figure 3 shows device performance for non-annealed and $240^{\circ} \mathrm{C}$ annealed photovoltaic devices of the type ITO/PBI/P3HT/Au. Short-circuit current density, opencircuit voltage, and fill factor are all increased for the higher temperature annealed device, leading to an improvement of power conversion efficiency going from $\eta=0.19 \%$ for the non-annealed device to $\eta=0.47 \%$ for the $240^{\circ} \mathrm{C}$ annealed sample. Annealing takes place prior to Au deposition.

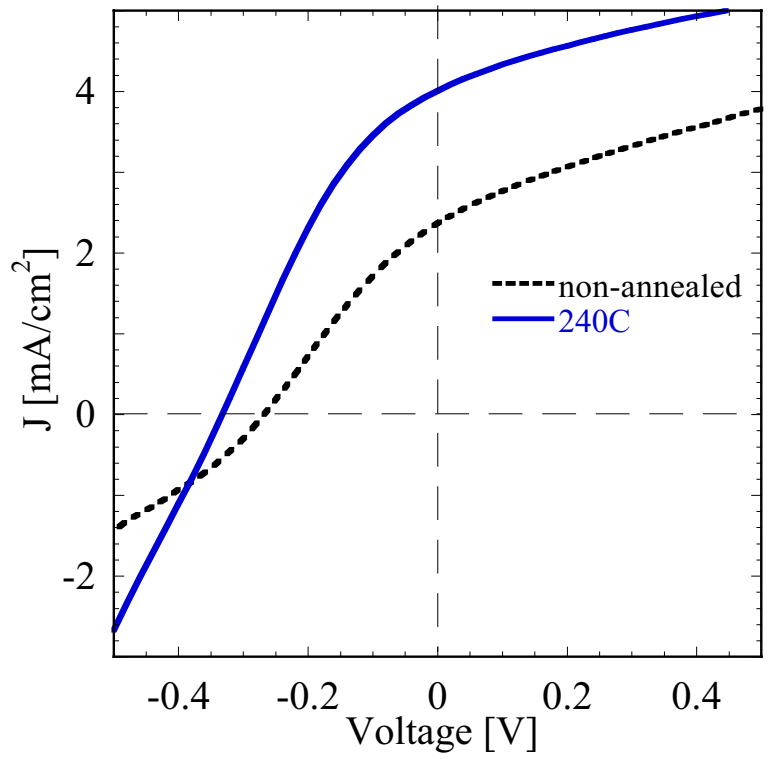

Fig 3. Current density - voltage characteristics for nonannealed (dotted black) and $240^{\circ} \mathrm{C}$ annealed (solid blue) devices.

\section{Effects of Polymer Solvent}

The film morphology is also noticeably affected by the choice of organic solvent used for the polymer deposition. Figure 4 shows absorption spectra for films spin-cast from chloroform and chlorobenzene solvents; both solutions are 8 $\mathrm{g} / \mathrm{l}$ concentration. The strength of the lowest wavelength peak is decreased with a corresponding increase in the strength of the two higher wavelength absorption peaks. These spectral changes are similar to those observed in the annealing experiments, indicating the same type of increased order is occurring. In addition, the two lower wavelength peaks are shifted about $10 \mathrm{~nm}$ higher going from the chloroform to the chlorobenzene sample. We conclude that chlorobenzene promotes a higher degree of ordering in P3HT films than chloroform. Experiments comparing the photovoltaic performance of chlorobenzene to chloroform devices are currently underway.

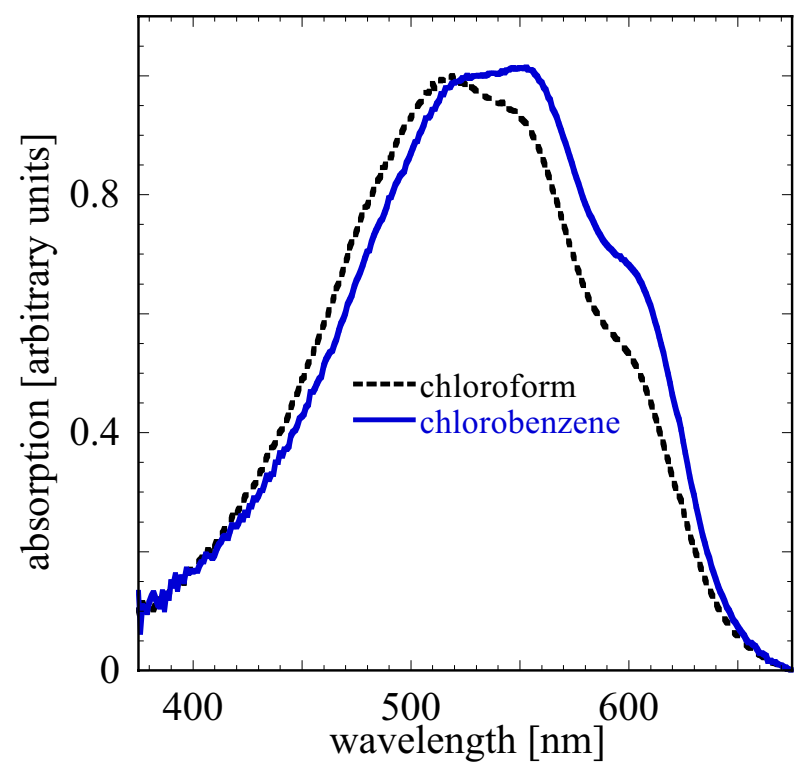

Fig 4. Absorption spectra for P3HT films spin-cast from chloroform (dotted black) and chlorobenzene (solid blue) solvents and annealed at $120^{\circ} \mathrm{C}$. Spectra are normalized at the peaks of $519 \mathrm{~nm}$ and $529 \mathrm{~nm}$, respectively.

\section{Conclusion}

We have shown that processing conditions strongly effect the morphology of polymer films, controlling the degree of polymer chain ordering and giving improved photovoltaic performance in organic-based solar cells.

The authors are grateful to an NREL Director's Discretionary Research and Development fund grant under the Department of Energy contract DE-AC-63-19GO10337. 


\section{References}

[1] A. J. Breeze, A. Salomon, D. S. Ginley, B. A. Gregg, H. Tillmann and H.-H. Horhold. "Polymer-perylene diimide heterojunction solar cells", Appl. Phys. Lett. 81 (2002) 3085-3087.

[2] X. Jiang, R. Osterbacka, O. Korovyanko, C. P. An, B. Horovitz, R. A. J. Janssen and Z. V. Vardeny.

"Spectroscopic studies of photoexcitations in regioregular and regiorandom polythiophene films", Adv. Func. Mater. 12 (2002) 587-597.

[3] M. Theander, O. Inganas, W. Mammo, T. Olinga, M. Svensson and M. R. Andersson. "Photophysics of

Substituted Polythiophenes", J. Phys. Chem. B 103 (1999)

7771-7780. 


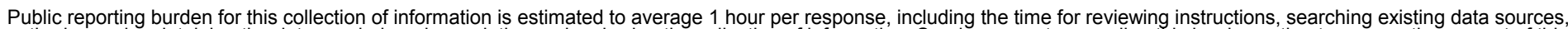

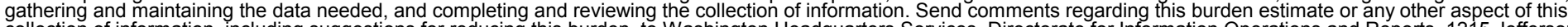

作

Davis Highway, Suite 1204, Arlington, VA 22202-4302, and to the Office of Management and Budget, Paperwork Reduction Project (0704-0188), Washington, DC 20503.
1. AGENCY USE ONLY (Leave blank)
2. REPORT DATE
May 2003
3. REPORT TYPE AND DATES COVERED
Conference Paper

4. TITLE AND SUBTITLE

The Effects of Processing Conditions on Polymer Photovoltaic Device Performance

5. FUNDING NUMBERS

6. $\mathrm{AUTHOR}(\mathrm{S})$
A. Breeze, D. Ginley, and B. Gregg

7. PERFORMING ORGANIZATION NAME(S) AND ADDRESS(ES)

National Renewable Energy Laboratory

1617 Cole Blvd.

Golden, CO 80401-3393

9. SPONSORING/MONITORING AGENCY NAME(S) AND ADDRESS(ES)

PVP3.2301

8. PERFORMING ORGANIZATION REPORT NUMBER

NREL/CP-590-33580

10. SPONSORING/MONITORING AGENCY REPORT NUMBER

11. SUPPLEMENTARY NOTES

12a. DISTRIBUTION/AVAILABILITY STATEMENT

National Technical Information Service

12b. DISTRIBUTION CODE

U.S. Department of Commerce

5285 Port Royal Road

Springfield, VA 22161

13. ABSTRACT (Maximum 200 words)

We will discuss recent results for the NREL polymer photovoltaics group. The work reported here explores the impact of polymer morphology on the physics and performance of polymer-based photovoltaic devices. By varying both the annealing temperatures and the solvent used for polymer deposition, we can alter the polymer chain morphology, thus shifting the absorption onset and shape and improving the charge transport properties of the resulting devices. The higher degree of order in the films results in increased photovoltaic performance.

14. SUBJECT TERMS

organic solar cells; polymer chain morphology; processing conditions

15. NUMBER OF PAGES

16. PRICE CODE

17. SECURITY CLASSIFICATION OF REPORT Unclassified
18. SECURITY CLASSIFICATION OF THIS PAGE Unclassified
19. SECURITY CLASSIFICATION OF ABSTRACT Unclassified
20. LIMITATION OF ABSTRACT

UL 